\title{
Economic Effects on Million Dollar Giving
}

\author{
Una Okonkwo Osili \\ Indiana University Lilly Family School of Philanthropy \\ Jacqueline Ackerman \\ Indiana University Lilly Family School of Philanthropy \\ Yannan Li \\ Indiana University Lilly Family School of Philanthropy
}

December 2014 


\title{
Economic Effects on Million Dollar Giving
}

\begin{abstract}
This study investigates the impact of economic factors on the number of charitable gifts of one million dollars or more within the United States using the Million Dollar List dataset. We investigate key donor groups: individuals, corporations, and foundations. Results indicate that individual donors are particularly responsive to underlying economic conditions; giving by

foundations tends to be counter-cyclical, and corporate giving is not significantly associated with macroeconomic factors. We also find that economic conditions vary in their influence on giving to subsectors, and gifts to public benefit and human services organizations increase significantly during periods of recession. Findings from our study have direct implications for philanthropists, fundraisers, and policy makes as they seek to understand how economic conditions impact large gifts.
\end{abstract}

Keywords:

Philanthropy

Economy

Giving

High net worth giving

Recession 


\section{Economic Effects on Million Dollar Giving}

\section{Introduction}

Million dollar gifts account for a significant share of U.S. charitable dollars; as an example, one study found that in 2000, 0.4 percent of families had incomes of \$1 million or more, but these families gave 16 percent of charitable dollars (Schervish \& Havens, 2003). Recent policy debates on growing wealth and income inequality in the U.S. have led to a great deal of interest in the charitable behavior of wealthy Americans (Piketty \& Saez, 2001). In general, charitable giving has been shown to be highly skewed, with several studies showing that high net worth donors contribute a disproportionately large share of all philanthropic dollars (Schervish \& Havens, 2001; Havens, O’Herlihy, \& Schervish, 2006). Scholars have also emphasized that understanding high net worth giving is an important component of philanthropy and the nonprofit sector.

Recent estimates suggest that U.S. charitable giving has grown over the past four decades at an annual rate of 6.8 percent (Giving USA, 2014). Overall, charitable giving increased from \$21 billion in 1970 to \$298 billion in 2012, and makes up two percent of GDP (Giving USA, 2014). Between 2007 and 2009, total charitable giving declined by 9.75 percent, with a 6.5 percent decline taking place between 2008 and 2009. During the recent economic downturn, there has been a great deal of interest in understanding how charitable giving and its composition have changed as a result of changing economic conditions. Research has documented how economic conditions have influenced charitable giving by individuals, foundations and corporations, as well as how changes have influenced giving to various subsectors, such as higher education, health, arts, and basic needs (Drezner, 2006; Congressional Budget Office, 
2011; List \& Peysakhovich, 2011). Understanding million dollar giving over the business cycle is an important aspect of philanthropy and the nonprofit sector, yet it remains underexplored.

This paper investigates how economic conditions have influenced large gifts over the past decade using a unique and newly available dataset on million dollar-plus gifts. Despite a growing interest in how the economy affects philanthropic activity, few studies have sought to disentangle the nature of this relationship with regard to specific types and levels of contributions, specifically for million dollar-plus gifts. To our knowledge, this paper is one of the first to establish empirical evidence of a link between economic conditions and million dollar giving, using a newly available dataset, the Million Dollar List (MDL).

Figure 1 provides some initial evidence that economic factors influence overall trends in gifts at the million dollar level. Existing research has examined the relationship between stock market performance and overall charitable giving. List and Peysakhovich (2011) find that giving is more likely to respond positively to increases in the S\&P 500 than it is to respond negatively to decreases in the S\&P 500. One particularly interesting finding is that changes in the S\&P 500 are shown to affect giving to charitable subsectors differently. For example, changes in giving to religion are not significantly associated with changes in the $S \& P$ 500, while giving for educational purposes follows changes in the S\&P 500 more closely.

Consistent with the literature, among the economic indicators that we examine, changes in giving at the million dollar level are correlated with the quarterly closing value of the S\&P 500 index (Figure 1), the quarterly unemployment rate, personal consumption expenditures, and the U.S. GDP, each adjusted for inflation.

[Figure 1 Here] 
This paper investigates how million dollar-plus giving (measured by the number of million dollar gifts) is affected by economic conditions. We disaggregate this giving by three key sources: households, foundations, and corporations. This research seeks to address two primary questions. First, we investigate how economic trends affect million dollar-plus giving by analyzing this giving across three broad donor types. Second, we examine million dollar gifts to various nonprofit subsectors, including human services and the arts, in order to discern the impact of economic conditions on particular subsectors.

We find significant differences between the three broad donor categories (individuals, corporations, and foundations) with regard to the impact of macroeconomic conditions on publicly announced million dollar-plus gifts. Specifically, giving by individuals is significantly influenced by current economic trends. The frequency of million dollar-plus gifts by individuals is diminished during times of economic adversity. Foundation giving appears to be countercyclical with many foundations increasing giving, particularly to human services organizations, during times of recession. Interestingly, million dollar giving by corporations appears to be relatively unaffected by macroeconomic conditions, and tends to be affected by industry-specific conditions. When we examine giving by subsector, economic indicators seem to impact million dollar giving to arts and higher education organizations most dramatically.

\section{Conceptual Framework: Giving by Households, Corporations, and Foundations}

Individuals comprise a key component of overall charitable giving, and make up nearly 75 percent of charitable giving annually (Giving USA, 2014). Studies of household charitable giving have primarily focused on motivations for charitable behavior, including models of altruism and "warm glow" (see for example Andreoni, 1993; Kingma, 1989). Along with these motivations, researchers have been particularly interested in understanding how household giving is influenced by economic and 
demographic factors including income, wealth, and tax policies. One testable hypothesis is that economic conditions will tend to have a larger impact on giving by individuals and households compared to their effect on foundations and corporations, given that individuals do not face same the institutional constraints that may influence corporate and foundation giving, such as payout requirements on foundations.

However, recent studies have also emphasized that non-economic motivations for individual charitable giving, such as desire for status and social pressure by fundraisers, may influence overall patterns of individual giving (DellaVigna, List, \& Malmendier, 2009). These models may be particularly relevant in explaining the giving patterns of wealthy donors (Lloyd, 2004). Duncan (2004) developed impact philanthropy, a model of altruism in which the donor gives in order to "make a difference." According to impact philanthropy, an individual donor might be motivated by the increased need that an economic downturn creates, and may respond by giving more. These studies suggest that household giving may be less closely linked to increases in the stock market and other economic conditions if donors perceive that their charitable contributions are more valuable to an organization during an economic downturn. In addition, social pressures cause charitable gifts to be sticky downward because of donors' desires to maintain or increase their previous levels of giving when encountering personal and impersonal forms of solicitation (Long, 1976).

Foundation giving makes up about 10 to 15 percent of all charitable giving (Giving USA Foundation, 2008). Existing research appears to suggest that macroeconomic conditions have less of an effect on foundation donors than on individual donors. Indeed, in a recent study there was no significant correlation between private foundation giving and macroeconomic or institutional variables (Lew \& Wójcik, 2009).

Corporate charitable giving typically makes up about five percent of all charitable dollars in any given year (Giving USA Foundation, 2008). A significant body of literature exists on the extent to which economic factors affect corporate giving. Much of the literature examines 
whether corporations engage in philanthropic activity in order to advance their profit goals versus corporate social responsibility objectives (Reich et al., 2011; Moir \& Taffler, 2004). Industry structure, state and local policies, size, and corporate profits for a given firm have been shown to have strong relationships with corporate charitable giving (Drezner, 2010; Giving USA Foundation, 2009; Seifert, Morris, \& Bartkus, 2003; Kitzmueller \& Shimshack, 2012). Corporate giving has also been shown to be influenced by firm and industry performance, as well as business needs (Urriolagoitia \& Vernis, 2012; Moir \& Taffler, 2004). Another testable hypothesis is that corporate giving may be less closely linked to overall economic conditions than individual giving. Although economic downturns have an aggregate negative effect on corporate charitable giving, this tends to depend on subsector or industry type rather than macroeconomic indicators (Amato \& Amato, 2007).

Several factors may contribute to foundation giving being less responsive to macroeconomic conditions. Noneconomic factors, such as using rolling averages to make grantmaking budgets and using reserves to make planned gifts, may outweigh economic factors in influencing foundation charitable giving (Foundation Center, 2010). Drezner (2010) suggests that grant-making priorities of corporate and private foundations are affected by these organizations' bottom lines, especially when giving to higher education. Indeed, some foundations may emphasize meeting social needs as a primary area of grant-making (Reich et al., 2011; Lew \& Wójcik, 2009). Foundations tend to be more proactive and devoted to selecting program areas in which to invest, and increase their giving during adverse economic periods (Katz, 2005).

Researchers have examined charitable giving during the Great Depression (Goldthorpe, 1941; Gruber \& Hungerman, 2005). In a seminal paper, List (2011) examined how changes in 
the economy impact overall giving trends. List showed that the Standard \& Poor's 500 index (S\&P 500) accounts for 40 percent of the variation in the percentage change of total annual charitable giving. Based on these results, individual donors tend to be more responsive to improvements than to declines in the overall economy. Only a handful of academic studies investigate the economic factors that influence overall levels of charitable giving.

\section{Data}

This paper uses the Million Dollar List (MDL), a publicly available data set providing an in-depth view of high net worth giving through a comprehensive picture of publicly announced gifts valued at $\$ 1$ million or greater originating in the United States (Indiana University Lilly Family School of Philanthropy, 2012). The Million Dollar List has been compiled by the Lilly Family School of Philanthropy at Indiana University (formerly the Center on Philanthropy) since 2000. The MDL provides a unique perspective on trends in giving at the highest levels by the wealthiest American individuals, corporations, foundations, and other grant-making nonprofit organizations. The main advantage of the MDL is that it provides gift-level information on a quarterly basis, allowing for better understanding of how overall economic conditions affect giving trends and patterns. This gift-level view contrasts with data sources that have been used in previous studies on charitable giving.

Most studies on U.S. charitable giving by individuals, corporations and foundations rely on household surveys and tax records. However, both types of data have clear strengths and limitations. The primary limitation of data based on tax return sampling is that this information typically only includes aggregate donations reported on an individual's tax return, which may not include all of their charitable giving. Additionally, tax data tends to provide aggregate information at the donor level (Rooney et al., 2001), and analysis based on tax data is restricted to the tax effects on itemized charitable giving (Wilhelm, 2006). Yet little evidence is provided about specific gifts, as the names of the organizations that receive these gifts may not be publicly available. The primary limitation of household surveys on 
charitable giving is that very few household data sources are available specifically on million dollar giving, making it extremely difficult to estimate differences at the highest levels of giving distributions (Wilhelm, 2007). With the lack of gift-specific data, and most data sources providing only annual household giving levels, it is hard to measure the impact of economic conditions on high net worth gifts, rather than on general giving.

The Million Dollar List's data collection sources include: the Chronicle of Philanthropy's monthly publication and attendant website, the Chronicle of Higher Education's weekly publication, NOZA Search's weekly announced gifts, Factiva, LexisNexis Academic, the Philanthropy News Digest from the Foundation Center, Google email alerts and the FoundationSearch database. Many of these sources provide daily and weekly updates. Once qualifying gifts are identified, researchers code each gift and enter it into a central database. Specific data that are coded for each gift include donor name, city, state, and type; recipient name, state, country, and subsector; gift amount and notes; source of information; date reported; and year and quarter of the donation. We note that there may be some variation in how data from different subsectors are represented on the MDL. For example, gifts to higher education may be overrepresented and gifts to religious organizations may be underrepresented, due to the different preferences of these types of organizations for publicity and media attention. Giving USA estimates that the Million Dollar List captures 25 percent of all gifts at this level in the U.S. (Giving USA, 2014).

In the sample used for this analysis, we primarily rely on publicly announced data, as tax data does not offer quarterly updates to reflect the specific time period of giving. Gifts made by individuals through bequest are excluded, as the decision making governing bequests may differ 
from individual gifts. ${ }^{1}$ Gifts marked as being given by "other" groups are also excluded. We focus the analysis on three major donor groups: individuals, foundations, and corporations and corporate foundations. These groups account for approximately 91 percent of the total number of gifts that reflect quarterly changes, and 83 percent of corresponding dollar values. All dollar figures are inflation adjusted to 2011 values.

There are some notable differences in the giving trends among the three primary donor types on the Million Dollar List (Table 1). In our sample, individual and household donors make up 37 percent of the gifts by number, but account for more than 60 percent of the total dollars on the list. The mean gift size for these donors is approximately $\$ 19$ million. On the other hand, foundation giving comprises 47 percent of the gifts on the Million Dollar List, while accounting for just 30 percent of total dollars. The mean gift size for foundations is approximately $\$ 7.6$ million. Lastly, corporations contributed nearly 16 percent of all gifts by number on the Million Dollar List, while accounting for nearly 9 percent of total dollars. Corporation gifts have a mean value of nearly $\$ 6.8$ million. These numbers illustrate the striking difference in the value of gifts contributed by individual donors as opposed to foundations and corporations. Among the subsectors receiving the million dollar gifts, higher education receives a significantly higher proportion, both of the number of gifts (47 percent) and value of the gifts (34 percent) (Table 2).

\section{[Table 1 Here]}

\section{[Table 2 Here]}

Based on the initial analysis of the Million Dollar List, a number of patterns have emerged. First, the data collection method employed since the project's inception in 2000 may underreport gifts made to religious organizations and small nonprofits, both of which are less

\footnotetext{
${ }^{1}$ Bequests may be accidental, as a consequence of uncertain lifespan and an imperfect market for life annuities (Davies, 1981; Hurd, 1989).
} 
likely to publicly report or obtain media coverage of such gifts. Second, specific gifts as reported may differ from the actual size of the gift or estimated value, for instance, of non-monetary contributions such as artwork, stock, or in-kind support. Finally, there may be some duplication in gift reporting due to variation in how the media covers these contributions and the timing of the reports.

\section{Methods}

To analyze the effects of economic influences on giving, we classify the Million Dollar List data by donor type and subsector. The key dependent variable of interest is the number of million dollar gifts by donor type and to a given subsector in each quarter. By studying the incidence (number) of gifts, rather than the dollar amount, we reduce the role of measurement error in our analysis.

For each donor type and subsector, the linear model

$$
\text { Number of Giftsds,t }=\alpha+\beta \text { Indicator }_{t}+\gamma \text { Year }_{t}+\zeta \text { Quarter }_{t}+\varepsilon_{d s, t}
$$

was used to estimate the impact of each economic indicator on the number of gifts received per quarter, where $d s$ represents a specific donor type to a specific subsector, Year represents a vector of year dummy variables, and Quarter represents a vector of quarter dummy variables. We assess the size and significance of the estimator for the economic indicator variable $(\beta)$, to determine whether it is associated with the number of gifts over the time period. We analyze the impact of each economic indicator on the number of gifts received per quarter for three different time periods: during the same quarter, and lagged both one and four quarters. We include the following economic indicators as independent variables in our analysis: S\&P 500 index, GDP, Personal Consumption Expenditures (PCE) index, unemployment rate, and recession (defined in Table 3). Quarter and year are also included as independent variables. 


\section{[Table 3 Here]}

The baseline model in our analysis is an OLS (Ordinary Least Squares) regression which tests the impact of economic conditions on million dollar-plus giving. We deal with potential problems associated with multicollinearity (where two or more variables are highly correlated) by using separate panels for each economic indicator. To ensure the robustness of the model, we also apply Poisson regression models. The Poisson model is typically used to model count data, here the number of Million Dollar List gifts.

\section{Results}

Economic Effects on Giving by Donor Type

Table 4 presents the baseline model. In this model, the dependent variable is the number of million dollar gifts by donor type in each quarter. We include the following independent variables in our analysis: S\&P 500 index, GDP, Personal Consumption Expenditures (PCE) index, unemployment rate, and recession. The S\&P 500 index is obtained from Yahoo! Finance, based on the closing price on the last day of the quarter (Yahoo! Finance, 2012). The unemployment rate is estimated by the Bureau of Labor Statistics (U.S. Bureau of Labor Statistics, 2012). GDP and Personal Consumption Expenditures are taken from the Bureau of Economic Analysis and seasonally adjusted at annual rate (U.S. Bureau of Economic Analysis, 2012). Recession, which is defined by the National Bureau of Economic Research, is included as a dummy variable for whether any months in a quarter were recessionary (NBER, 2012). See Table 3 for more detailed definitions of the independent variables utilized for this study.

\section{[Table 4 Here]}

Giving by Individuals. We begin our analysis by studying million dollar giving by individuals. In general, the results in Table 4 show that individual donors at the million dollar 
level tend to be responsive to overall economic conditions. In our analysis, we discuss the economic indicators that are closely associated with individual giving.

First, we analyze the relationship between the stock market and individual million dollar giving, as this relationship has been explored in the existing literature. We find that a 100-point increase in the value of the S\&P 500 index in a given quarter is associated with an increase of more than 17 gifts from individual donors over the same quarter. Existing research has examined the relationship between stock market performance and overall charitable giving. List and Peysakhovich (2011) find that giving is more likely to respond positively to increases in the S\&P 500 than it is to respond negatively to decreases in the S\&P 500.

The Personal Consumption Expenditures also significantly influences the number of individual gifts in a given quarter: a one-point increase in the PCE index is associated with an increase of 19 gifts in the same quarter. This represents an economically significant change in individual million dollar giving, since the average number of individual gifts within a quarter is approximately 148 .

Importantly, million dollar giving by individuals is negatively associated with unemployment. This result further supports the finding that million dollar giving by individuals tends to be influenced by the business cycle. A one percentage point increase in the unemployment rate is associated with a 42-gift decrease by individuals in the same quarter.

Additional findings support individual giving at the million dollar level tends to be procyclical; changes in GDP are also positively associated with individual million dollar donations. Specifically, an increase of $\$ 100$ billion in the GDP is associated with an 18-gift increase in giving by individuals during the same quarter. We also find that recession, though not statistically significant, is negatively related to the number of individual gifts: when the U.S. is in 
a recession in a particular quarter, million dollar giving by individuals tends to fall by nine gifts in the same quarter.

Giving by Foundations. We now turn to examine the impact of macroeconomic factors on million dollar gifts by foundations. In general, million dollar gifts by foundations appear to be less closely associated with overall economic conditions compared to gifts by individuals. Interestingly, we find that only one of the macroeconomic indicators is associated with changes in million dollar giving by foundations in the same quarter. Million dollar giving by foundations appears to be counter-cyclical. We find that only the recession variable is significantly positively associated with giving by foundations in the same quarter. During a quarter in which the United States was in economic recession, foundations were shown to give 55 more million dollar gifts and grants on average. This is a substantial change in foundation giving, considering that the average number of such gifts and grants in any given quarter is about 187 . No other economic conditions appear to be significantly associated with foundation giving in the same or the next quarter. However, GDP and PCE appear to significantly impact the number of foundation gifts one year later (see tables in Robustness section). This appears consistent with the counter-cyclical pattern we have noted.

To shed light on these results, we note that foundations may face different incentives and constraints in their million dollar giving decisions, compared with individuals. In particular, foundations may respond to adverse economic conditions by giving more million dollar gifts and grants. The increase in foundation giving during quarters when the U.S. is experiencing an economic recession seems to support this hypothesis.

Giving by Corporations. Corporate million dollar giving, interestingly, showed no significant association with any of the macroeconomic indicators for the same quarter. Specifically, we did not find a significant relationship between corporate donations of one million dollars or more and any of the five major economic indicators tested, including the S\&P 500 index, overall unemployment, GDP, personal consumption, and a recession dummy variable. 
This could indicate that corporate donors respond to macroeconomic conditions differently than other types of donors.

This finding is consistent with several other studies that have noted that overall macroeconomic factors are less influential determinants of corporate giving compared to firm and industry variables (Amato \& Amato, 2007; Urriolagoitia \& Vernis, 2012). In addition, these findings provide support for Levy and Shatto's "good citizen” hypothesis that the level of corporate contributions moves counter-cyclically, and that these contributions actually rise when economic activity declines during a recession (Levy \& Shatto, 1978). As a growing number of corporations seek to implement strategic corporate objectives that drive when to give, to what extent, and to whom, it implies a weaker relationship between overall economic trends and corporate giving (Urriolagoitia \& Vernis, 2012). Instead, corporate giving may be more closely influenced by firm and industry performance (Amato \& Amato, 2007; Urriolagoitia \& Vernis, 2012), societal and business needs (Reich et al., 2011; Moir \& Taffler, 2004), and CEO interests and affiliations (Werbel \& Carter, 2002).

\section{Economic Effects on Giving by Subsector}

Our second research question asked to what extent million dollar giving to specific causes or subsectors changes in response to macroeconomic conditions. We are particularly interested in whether individuals, foundations, and corporations give more to support basic needs and human services during recessions.

Table 5 presents the baseline results of this analysis. The findings in Table 5 suggest that there is considerable variation in giving trends by subsector and donor type, and that the 
economic effects on those trends depend on the institutions and causes that receive million dollar gifts.

\section{[Table 5 Here]}

We analyze the economic effects on each subsector and discovered that the results for human services, arts, health, and higher education organizations are particularly striking. We therefore focus on giving to basic needs and public and societal benefit organizations, as this includes many institutions that provide housing, food, and other needs especially in demand during times of economic downturn. Such organizations include local United Way organizations, the American Red Cross, Salvation Army, and more. We find that giving by foundations and corporations to basic needs is counter-cyclical, as these organizations give more million dollarplus gifts to support human services during recessionary periods. In quarters where there is at least one month of recession in the U.S., corporate gifts at the million dollar-plus level rise by almost 14 gifts in the same quarter. This effect is even more evident in foundation giving: during quarters including at least one month of economic recession, foundation gifts rise by approximately 25 gifts in the same quarter. In the same quarter, an increase in the unemployment rate leads to a decrease in the number of individual gifts, and the association is significant for all subsectors except health. The results suggest that foundations are more responsive to the increasing demand for gifts to human services and public benefit organizations during periods of economic downturn, whereas individual giving tends to decline when unemployment rises.

Compared to other subsectors, million dollar giving to arts and culture appears to show the most volatility. Relationships between the economic variables and the number of gifts directed toward arts, culture and humanities organizations also appear to be significant for all donor types in the same quarter. There is an increase in foundation giving to these organizations 
during periods of recession. Corporations and individuals appear to give less to arts, culture, and humanities organizations when the unemployment rate increases. Individual giving at the million dollar-plus level to arts and culture organizations is associated with changes in the S\&P 500 index, GDP, PCE index, and unemployment. When the S\&P 500, GDP, or PCE increases, giving by individuals to these organizations increases as well. It may be that giving to these particular causes may be considered a lower priority during periods of economic difficulty, particularly when compared to causes such as human services and health, which vary much less even when holding economic changes constant.

When analyzing the health subsector, we find no significant association between individual or foundation gifts at the million dollar-plus level and any of the economic indicators analyzed.

Finally, economic indicators appear to predict changes to giving for the higher education subsector for individuals, but not for corporations or foundations. Giving from individuals to higher education increases with an increase of the S\&P 500, the GDP, and the PCE during the same quarter. Thus million dollar gifts from individuals to higher education organizations appear cyclical: with an improvement in the economy, giving increases, and vice versa.

\section{Robustness Checks}

\section{Lagged Dependent Variables}

To account for the lagged effect of economic factors on million dollar giving, we conducted all analyses with the dependent variable lagged one quarter, as well as four quarters. These results are available upon request. The models examining giving by key donor types (individuals, foundations, and corporations) largely support the results in the non-lagged models. 
When lagged one year, the relationship between giving by all donor types to the human services subsector appears to be impacted by economic indicators. The human services subsector is the only one where, accounting for the one year lagged effect, three economic indicators are still significant (GDP, PCE index, and unemployment rate).

In the quarter following a recession, giving increases significantly, from all donor types combined, to public benefit and human services organizations. To reinforce this finding, giving by all donors combined, to arts, culture, and humanities organizations, decreases significantly in the quarter following an uptick in unemployment.

\section{Poisson Model}

One concern in our analysis is that the dependent variables are count variables and may not be normally distributed. A linear regression model may therefore not fully capture the underlying distribution of this type of data. To check the robustness of our results, we conducted the same analyses using Poisson regression rather than Ordinary Least Squares (OLS). Poisson results for the donor type shown in Table 6 below. We also conducted Poisson analyses for the subsectors, and for both donor type and subsector with the dependent variable lagged both one and four quarters, and these results are available upon request.

\section{[Table 6 Here]}

Using Poisson regression to test results for the donor type (baseline model in Table 4), we find generally consistent results as the OLS baseline model. In fact, the results from the Poisson regressions supported the previous results but also showed that the variables seem to have a more lasting impact further into the future. For individuals, both the stock market and unemployment rate appear to affect individual giving. Unlike our OLS model, the Poisson regression results for individuals showed that the PCE index becomes significant with a one quarter lag and the recession becomes highly significant with a one year lag supporting the pro-cyclical view of how 
the economy impacts million dollar giving by individuals. For foundation giving, the Poisson regression results indicate that the unemployment rate lagged a quarter and a year, recession lagged a quarter, and S\&P 500 lagged a year become significant all supporting previous results showing foundation giving as counter-cyclical.

The Poisson model yielded more significant results for corporations. GDP and PCE are significantly positively associated with the incidence of million dollar-plus corporate giving for all time periods. The results are mixed as the recession variable indicates counter-cyclical behavior and the GDP and PCE variables indicate pro-cyclical behavior.

Using Poisson regression to test results for the subsector type (baseline model in Table 5) confirms many of our above findings, including that giving to human services and public benefit organizations is pro-cyclical for individual donors, and counter-cyclical for corporate and foundation donors. Unlike the OLS analysis, the Poisson regression results show that the key variables that influence gifts directed toward organizations in the arts, culture and humanities by corporations and individuals are significant in each time period. Poisson results also indicate that foundation giving is positively affected by both a recession in the same quarter and previous quarter. Overall, the Poisson results confirm that foundation increase gifts to arts, culture, and humanities during times of recession but giving from corporations and individuals increases as GDP and PCE increase.

Overall, our Poisson results seem to confirm and expand on findings from our OLS results. We previously showed that economic indicators affect million dollar giving by individuals for the arts and higher education subsectors. Our Poisson results demonstrate that these impacts are felt across all four of these major subsectors. For foundation giving, the new results confirm a counter-cyclical pattern for human services, arts, and higher education 
subsectors, and demonstrate that foundations seem most responsive to the recession indicator.

These results further show that the impact of economic conditions on corporate giving is felt in both the short- and longer-terms, and that PCE and GDP seem to elicit the most response in the number of gifts.

\section{Conclusions}

There is growing public and policy interest in the potential for philanthropy to meet societal challenges. Despite a growing number of empirical studies on charitable giving, there have been very few studies that examine million dollar gifts, due in part to data limitations. ${ }^{2}$ Using a newly available dataset on million dollar giving, we find important differences in how million dollar-plus giving is influenced by economic conditions among the three primary types of donors. Individual donors are particularly responsive to underlying economic conditions as measured by the S\&P 500 index, as well as other key economic variables. We find that a 100-point increase in the value of the S\&P 500 index in a given quarter is associated with an increase of more than 17 gifts from individual donors over the same quarter, and an increase of 18 gifts for the following quarter. Similarly, individual giving at this level is negatively correlated with unemployment and positively correlated with GDP growth.

In contrast to our findings on individual giving, we find that million dollar giving by foundations tends to be counter-cyclical. During quarters in which there is at least one month of

\footnotetext{
${ }^{2}$ There is a small but growing body of research and data on million dollar giving, including The Coutts Million Pound Donors Report (Breeze, 2009) and The 2010 Bank of America Merrill Lynch Study of High Net Worth Philanthropy (Center on Philanthropy at Indiana University, 2010).
} 
recession, foundations appear to increase their giving of million dollar-plus gifts and grants. An important finding is that the incidence of corporate million dollar giving is not significantly associated with overall macroeconomic factors.

Relevant to public policy debates, we find that economic conditions influence giving by subsector in significant ways. In particular, increased gifts are targeted toward human service and public benefit organizations. Economic indicators such as the S\&P 500 index, GDP and PCE also indicate more lasting effects on donations to these organizations. These trends seem to indicate a concerted effort on the part of foundations to address adverse economic conditions and societal and human needs. 


\section{References}

Amato, L. H. \& Amato, C. H. (2007). The effects of firm size and industry on corporate giving. Journal of Business Ethics, 72 (3), 229-241.

Andreoni, J. (1993). An experimental test of the public-goods crowding-out hypothesis. American Economic Review. 83 (5). 1317-1327.

Breeze, B. (2009). The Coutts million pound donors report. Canterbury: The University of Kent. Center on Philanthropy at Indiana University. (2010). Bank of America Merrill Lynch study of high net worth philanthropy. Indianapolis: Bank of America.

Congressional Budget Office. (2011). Options for Changing the Tax Treatment of Charitable Deductions. Congress of the United States.

Davies, J. B. (1981). Uncertain lifetime, consumption, and dissaving in retirement. Journal of Political Economy, 89 (3), 561-577.

DellaVigna, S., List, J. A., \& Malmendier, U. (2009). Testing for altruism and social pressure in charitable giving. NBER Working Paper No. 15629.

Drezner, N. D. (2006) Recessions and Tax-Cuts: Economic Cycles’' Impact on Individual Giving, Philanthropy, and Higher Education. International Journal of Educational Advancement. 4(6), 289-305.

Drezner, N. D. (2010). Fundraising in a Time of Economic Downturn: Theory, Practice and Implications - An editorial call to action. International Journal of Education Advancement. 9(4), 191-195.

Duncan, B. (2004). A theory of impact philanthropy. Journal of Public Economics, 88, 2159 2180.

Foundation Center. (2010). Moving Beyond the Economic Crisis. Research Advisory. 
Giving USA: The Annual Report on Philanthropy for the Year 2013 (2014). Chicago: Giving USA Foundation.

Giving USA Foundation. (2008). Giving During Recessions and Economic Slowdowns. Giving USA Spotlight. (3).

Giving USA Foundation. (2009). Giving Recovery after Economic Depression or Recession. Giving USA Spotlight. (2).

Goldthorpe, H. (1941). Trends in philanthropy. The Journal of Higher Education 12 (2), 73-80. Ohio State University Press.

Gruber, J. \& Hungerman, D. M. (2005) Faith-Based Charity and Crowding Out During the Great Recession. National Bureau of Economic Research. Cambridge, MA.

Havens, J., O'Herlihy, M., \& Schervish, P. (2006). Charitable giving: How much, by whom, to what, and how? In W. Powell, \& R. Steinberg, The Nonprofit Sector: A Research Handbook (542-567). New Haven, CT: Yale University Press.

Hurd, M. D. (1989). Mortality risk and bequests. Econometrica, 57 (4), 779-813.

Indiana University Lilly Family School of Philanthropy. (2012) Million Dollar List. Retrieved from http://www.milliondollarlist.org.

Katz, S. N. (2005). What Does It Mean to Say That Philanthropy Is "Effective"? The Philanthropists' New Clothes. Proceedings of the American Philosophical Society, Vol. 149, No. 2, 123-131.

Kingma, B. R. (1989). An Accurate Measurement of the Crowd-out Effect, Income Effect, and Price Effect for Charitable Contributions. Journal of Political Economy. 97(5). 11971207.

Kitzmueller, M. \& Shimshack, J. (2012). Economic Perspectives on Corporate Social Responsibility. Journal of Economic Literature, 50(1), 51-84. 
Levy, F. K. \& Shatto, G. M. (1978). The evaluation of corporate contributions. Public Choice, 33(1), 19-28.

Lew, S. \& Wójcik, D. (2009). The Cultures of Philanthropy: Private Foundation Governance in the USA, the UK, Germany, and Japan. Retrieved from http://dx.doi.org/10.2139/ssrn.1508858.

List, J.A. (2011). The Market for Charitable Giving. Journal of Economic Perspectives. 25 (2), 157-180.

List, J. A. \& Peysakhovich, Y. (2011). Charitable Donations are More Responsive to Stock Market Booms than Busts. Economics Letters, 110, 166-169.

Lloyd, T. (2004). Why rich people give. Association of Charitable Foundations.

Long, S. H. (1976). Social pressure and contributions to health charities. Public Choice, 28(1), $55-66$.

Moir, L. \& Taffler, R. J. (2004). Does corporate philanthropy exist? Business giving to the arts in the U.K. Journal of Business Ethics, 54 (2), 149-161.

National Bureau of Economic Research (NBER). (2012). US business cycle expansions and contractions. Retrieved from http://www.nber.org/cycles.html.

Pikkety, T., \& Saez, E. (2001). Income Inequality in the United States, 1913-1998 (series updated to 2000 available) (No. 8467). National bureau of economic research.

Reich, R., Wimer, C., Mohamed, S., \& Jambulapati, S. (2011). Has the great recession made Americans stingier? In The Great Recession, D. B. Grusky, B. Western \& C. Wimer., (Eds.). Russell Sage Foundation, 294-313. 
Rooney, P. M., Steinberg, K. S., \& Schervish, P. G. (2001). A methodological comparison of giving surveys: Indiana as a test case. Nonprofit and Voluntary Sector Quarterly, 30, 551568.

Schervish, P. G. \& Havens, J. J. (2001). Wealth and the Commonwealth: New Findings on Wherewithal and Philanthropy. Nonprofit and Voluntary Sector Quarterly. 30(1), 5-25.

Schervish, P. G. \& Havens, J. J. (2003). New Findings on the Patterns of Wealth and Philanthropy. Chestnut Hill, MA: Social Welfare Research Institute, Boston College.

Seifert, B., Morris, S. A., \& Bartkus, B. R. (2003). Comparing Big Givers and Small Givers: Financial Correlates of Corporate Philanthropy. Journal of Business Ethics, 45 (3), 195211.

U.S. Bureau of Economic Analysis. (2012). GDP and the National Income and Product Account (NIPA) historical tables. Retrieved from http://www.bea.gov/iTable/index_nipa.cfm.

U.S. Bureau of Labor Statistics. (2012). Local force statistics from the current population survey. Retrieved from http://www.bls.gov/cps/.

Urriolagoitia, L. \& Vernis, A. (2012). May the Economic Downturn Affect Corporate Philanthropy? Exploring the Contribution Trends in Spanish and U.S. Companies. Nonprofit and Voluntary Sector Quarterly, 41, 759-785.

Werbel, J. \& Carter, S. M. (2002). The CEO's influence on corporate foundation giving. Journal of Business Ethics, 40 (1), 47-60.

Wilhelm, M. O. (2006). New data on charitable giving in the PSID. Economics Letters, 92, 2631.

Wilhelm, M. O. (2007).The quality and comparability of survey data on charitable giving. Nonprofit and Voluntary Sector Quarterly, 36 (1), 65-84. 
Yahoo! Finance. (2012). S\&P 500 Historical Prices. Retrieved from http://finance.yahoo.com/q/hp?s=^GSPC+Historical+Prices. 
Figures and Tables

Figure 1: Million dollar-plus gifts by donor type and the S\&P 500

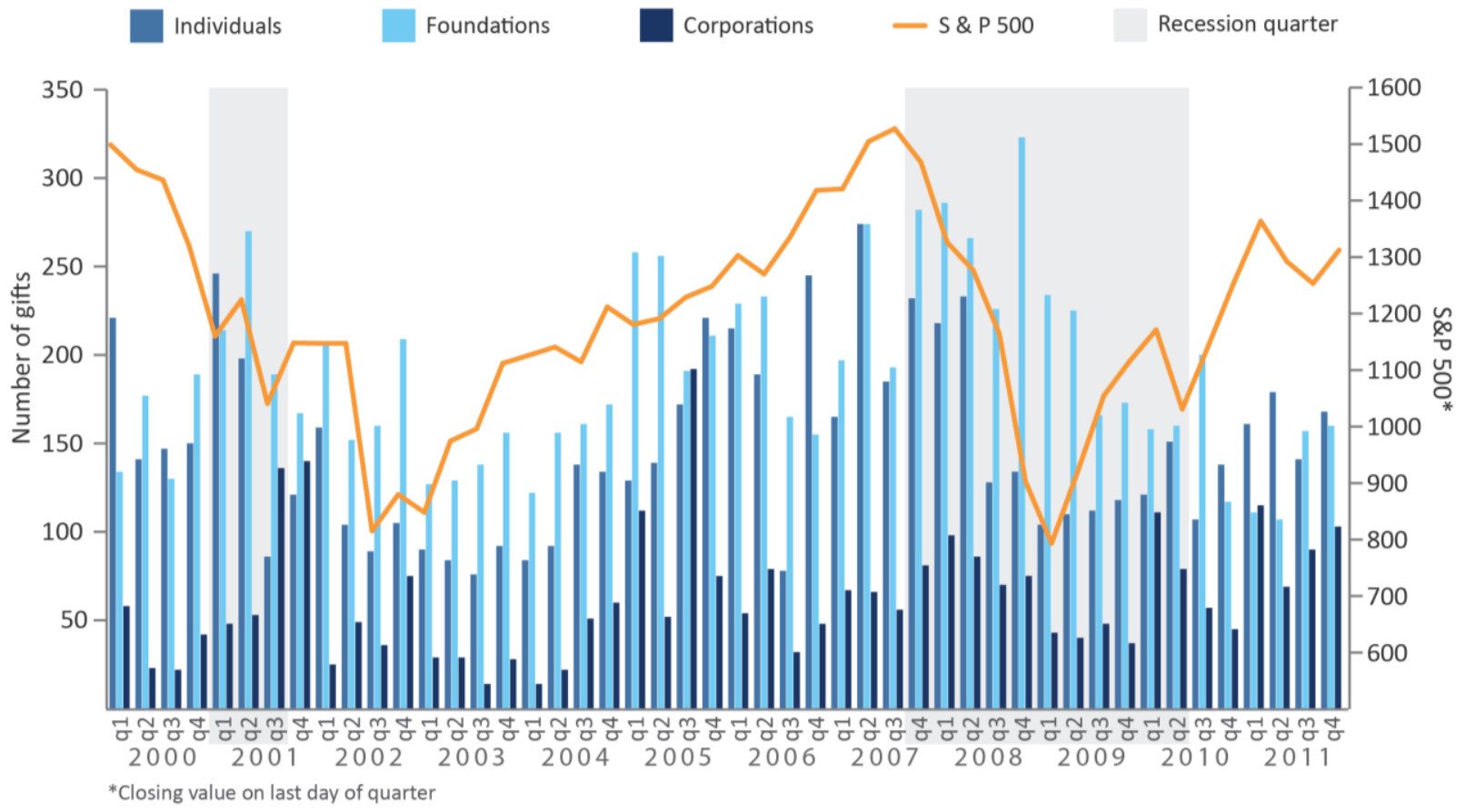

Table 1: Million dollar-plus giving by donor type, 2000-2011

\begin{tabular}{|c|c|c|c|c|c|}
\hline & All Donors & Individuals & Corporations & & Foundations \\
\hline Total dollar & 226,000 & $\begin{array}{l}137,000 \\
(60.62 \%)\end{array}$ & \multicolumn{2}{|l|}{$(8.98 \%)$} & $\begin{array}{l}68,200 \\
(30.18 \%)\end{array}$ \\
\hline Mean dollar & 11.80 & 19.30 & \multicolumn{2}{|l|}{6.77} & 7.60 \\
\hline Median dollar & 2.38 & 2.61 & \multicolumn{2}{|l|}{1.70} & 2.44 \\
\hline$N$ & 19,080 & $\begin{array}{l}7,092 \\
(37.17 \%)\end{array}$ & \multicolumn{2}{|l|}{$(15.74 \%)$} & $\begin{array}{c}8,984 \\
(47.09 \%)\end{array}$ \\
\hline \multicolumn{6}{|c|}{$\begin{array}{l}\text { Notes: Donors only include individuals, corporations and foundations. Dollar amount is in millions and inflation adjusted } \\
\text { to } 2011 \text { values. }\end{array}$} \\
\hline \multirow[b]{2}{*}{ Total dollar } & $\begin{array}{c}\text { Human } \\
\text { Services \& } \\
\text { Public/Societal } \\
\text { Benefit }\end{array}$ & $\begin{array}{c}\text { Arts, Culture, } \\
\text { Humanities }\end{array}$ & Health & $\begin{array}{l}\text { Higher } \\
\text { Education }\end{array}$ & $\begin{array}{c}\text { Other } \\
\text { Subsectors }\end{array}$ \\
\hline & $\begin{array}{l}15,800 \\
(6.99 \%)\end{array}$ & $\begin{array}{l}12,000 \\
(5.31 \%)\end{array}$ & $\begin{array}{l}13,900 \\
(6.15 \%)\end{array}$ & $\begin{array}{l}76,400 \\
(33.79 \%)\end{array}$ & $\begin{array}{l}108,000 \\
(47.77 \%)\end{array}$ \\
\hline
\end{tabular}




\begin{tabular}{cccccc}
\cline { 2 - 5 } Mean dollar & 4.95 & 7.94 & 9.19 & 8.48 & N/A \\
\cline { 2 - 5 } Median dollar & 1.85 & 2.10 & 2.58 & 2.54 & N/A \\
\hline \multirow{2}{*}{$N$} & 3,198 & 1,509 & 1,511 & 9,011 & 3,851 \\
& $(16.76 \%)$ & $(7.91 \%)$ & $(7.92 \%)$ & $(47.23 \%)$ & $(20.18 \%)$ \\
& & & & \\
\hline
\end{tabular}

Note: Dollar amount is in millions and inflation adjusted to 2011 values.

Table 3: Independent variable descriptions

\begin{tabular}{|c|c|c|}
\hline $\begin{array}{l}\text { Independent } \\
\text { Variable }\end{array}$ & Definition & Source \\
\hline $\begin{array}{l}\text { Standard \& Poor's } \\
500 \text { Index } \\
(\text { S\&P 500) }\end{array}$ & $\begin{array}{l}\text { The index uses the closing price on the last day of the quarter. It } \\
\text { represents the changes in stock market based on the } \\
\text { performance of the } 500 \text { largest capitalization stocks trading in } \\
\text { the United States. }\end{array}$ & Yahoo! Finance \\
\hline $\begin{array}{l}\text { Gross Domestic } \\
\text { Product } \\
\text { (GDP) }\end{array}$ & $\begin{array}{l}\text { Gross domestic product (GDP) measures the value of final } \\
\text { goods and services produced in the United States in a given } \\
\text { period of time. The GDP measure is in } 2005 \text { dollar value. }\end{array}$ & $\begin{array}{l}\text { U.S. Bureau of } \\
\text { Economic Analysis }\end{array}$ \\
\hline $\begin{array}{l}\text { Personal Consumption } \\
\text { Expenditures Index } \\
\text { (PCE) }\end{array}$ & $\begin{array}{l}\text { PCE includes goods and services purchased by individuals, the } \\
\text { operating expenses of nonprofit institutions serving individuals, } \\
\text { the value of food, fuel, clothing, rent of dwellings, the financial } \\
\text { services received in kind by individuals, and net purchases of } \\
\text { used goods. }\end{array}$ & $\begin{array}{l}\text { U.S. Bureau of } \\
\text { Economic Analysis }\end{array}$ \\
\hline Unemployment Rate & $\begin{array}{l}\text { Unemployment rate is the estimated percentage of unemployed } \\
\text { people aged } 16 \text { years and older. }\end{array}$ & $\begin{array}{l}\text { U.S. Bureau of } \\
\text { Labor Statistics }\end{array}$ \\
\hline Recession & $\begin{array}{l}\text { Recession is identified by the NBER definition of significant } \\
\text { declines in economic activities, see: } \\
\text { http://www.nber.org/cycles/recessions.html }\end{array}$ & $\begin{array}{l}\text { National Bureau of } \\
\text { Economic Research }\end{array}$ \\
\hline
\end{tabular}

Note: Dollar amount of MDL gifts is converted into 2005 dollar value for regression purposes; the descriptive analysis of MDL gifts uses 2011 dollar values. 
Table 4: Impact of economic indicators on incidence of million dollar-plus giving in the same quarter

Dependent variable: Number of million-dollar-plus gifts per quarter by each donor type

Notes: Each cell shows a separate Ordinary Least Squares (OLS) regression with a different independent variable as an indicator economic health $(\beta)$, reporting the variable's coefficient from a regression: Number of Gifts ${ }_{d, t}=\alpha+\beta$ Indicator $_{t}+\gamma$ Year $_{t}+\zeta$ Quarter $_{t}+\varepsilon_{d s, t}$.

Panel A: S\&P 500

All Donors Individuals Corporations Foundations

$\beta: \mathrm{S} \& \mathrm{P} 500$

$\begin{array}{llll}0.0611 & 0.1733 * * * & -0.0279 & -0.0843 \\ (0.0639) & (0.0385) & (0.0354) & (0.0541)\end{array}$

Panel B: GDP

All Donors Individuals Corporations Foundations

$\beta$ : GDP

$0.1836 * * \quad 0.1792 * * * \quad-0.0084 \quad 0.0128$

$(0.0871)$

$(0.0468)$

$(0.0376)$

$(0.0774)$

Panel C: PCE

All Donors Individuals Corporations $\quad$ Foundations

$\beta: \mathrm{PCE}$

$\begin{array}{llll}16.6977 * & 18.5623 * * * & 5.0141 & -6.8788 \\ (9.4926) & (6.4946) & (4.3684) & (8.3701)\end{array}$

Panel D: Unemployment Rate

All Donors Individuals Corporations $\quad$ Foundations

$\beta$ : Unemployment Rate

$\begin{array}{llll}-39.1374 * * & -42.3727 * * * & 11.5680 & -8.3327 \\ (16.7717) & (12.9871) & (12.4406) & (18.4559)\end{array}$

Panel E: Recession

\begin{tabular}{lcccc} 
& All Donors & Individuals & Corporations & Foundations \\
\cline { 2 - 5 }$\beta$ : Recession & 54.6049 & -9.0370 & 9.0000 & $54.6420 * * *$ \\
& $(34.1203)$ & $(21.1247)$ & $(6.6027)$ & $(12.8455)$ \\
\hline$N$ & 19,077 & 7,092 & 3,003 & 8,982 \\
\hline
\end{tabular}

Notes: Each cell shows a separate Ordinary Least Squares (OLS) regression with a different independent variable as an indicator economic health $(\beta)$, reporting the variable's coefficient from a regression: Number of Gifts,$t=\alpha+\beta$ Indicator $_{t}+$ $\gamma$ Yeart $_{t}+\zeta$ Quarter $_{t}+\varepsilon d s, t$.

Robust standard errors in parentheses.

***Significant at the 1 percent level.

**Significant at the 5 percent level.

*Significant at the 10 percent level. 
Table 5: Impact of economic indicators on incidence of million dollar-plus giving to causes by subsector in the same quarter

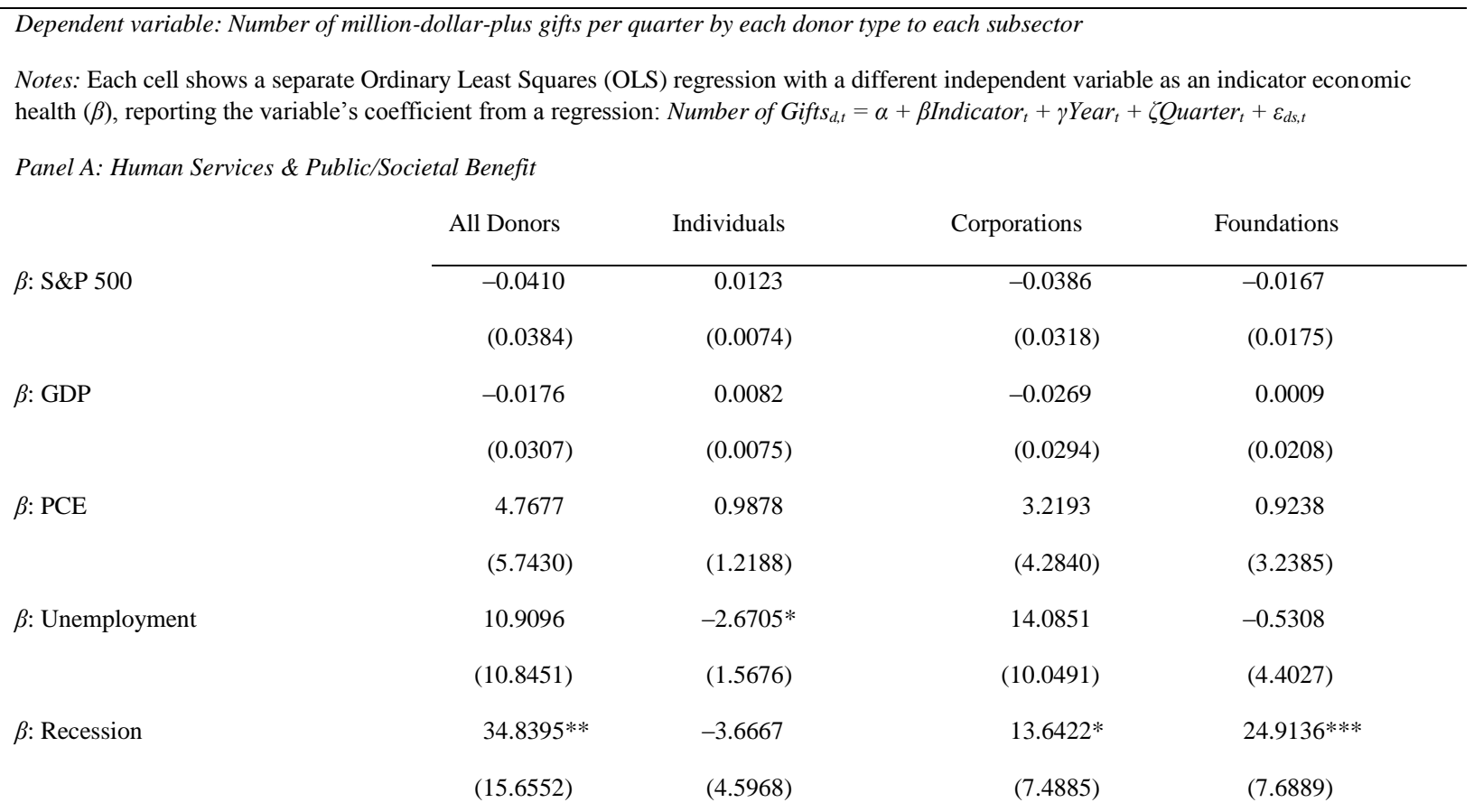

\begin{tabular}{|c|c|c|c|c|}
\hline \multicolumn{5}{|c|}{ Panel B: Arts, Culture, Humanities } \\
\hline & All Donors & Individuals & Corporations & Foundations \\
\hline \multirow[t]{2}{*}{$\beta: \mathrm{S} \& \mathrm{P} 500$} & 0.0090 & $0.0180^{* * *}$ & 0.0005 & -0.0078 \\
\hline & (0.0116) & $(0.0066)$ & $(0.0071)$ & $(0.0119)$ \\
\hline \multirow[t]{2}{*}{$\beta$ : GDP } & 0.0152 & $0.0137 * *$ & $0.0132 *$ & -0.0094 \\
\hline & $(0.0119)$ & $(0.0057)$ & $(0.0069)$ & $(0.0132)$ \\
\hline \multirow[t]{2}{*}{$\beta: \mathrm{PCE}$} & 0.4366 & $1.5820^{*}$ & $2.2293^{* *}$ & -2.8772 \\
\hline & $(1.2726)$ & $(0.9079)$ & $(1.0477)$ & $(1.2466)$ \\
\hline \multirow[t]{2}{*}{$\beta:$ Unemployment } & -3.8131 & $-3.2401 * *$ & $-3.8990 * *$ & 2.8885 \\
\hline & $(2.4405)$ & $(1.4175)$ & $(1.5824)$ & $(2.8308)$ \\
\hline \multirow[t]{2}{*}{$\beta$ : Recession } & 3.7407 & -1.4198 & -1.1598 & $6.2099 *$ \\
\hline & (5.0894) & $(2.4152)$ & $(1.0191)$ & (3.6105) \\
\hline \multicolumn{5}{|l|}{ Panel C: Health } \\
\hline & All Donors & Individuals & Corporations & Foundations \\
\hline \multirow[t]{2}{*}{$\beta: \mathrm{S} \& \mathrm{P} 500$} & 0.0052 & 0.0033 & -0.0024 & 0.0040 \\
\hline & $(0.0091)$ & $(0.0049)$ & $(0.0029)$ & $(0.0062)$ \\
\hline \multirow[t]{2}{*}{$\beta: \mathrm{GDP}$} & 0.0074 & 0.0035 & -0.0002 & 0.0035 \\
\hline & $(0.0081)$ & $(0.0054)$ & $(0.0025)$ & $(0.0052)$ \\
\hline \multirow[t]{2}{*}{$\beta:$ PCE } & -0.6044 & 0.0092 & -0.1412 & -0.5559 \\
\hline & (1.3328) & $(0.6379)$ & $(0.3617)$ & (1.0040) \\
\hline
\end{tabular}




\begin{tabular}{|c|c|c|c|c|}
\hline \multirow[t]{2}{*}{$\beta$ : Unemployment } & -0.1365 & 0.1216 & 1.0917 & -0.9558 \\
\hline & $(2.4463)$ & $(1.7440)$ & $(0.8648)$ & $(1.3578)$ \\
\hline \multirow[t]{2}{*}{$\beta$ : Recession } & 4.6049 & 2.9630 & 2.1290 & -0.5062 \\
\hline & $(6.2417)$ & $(2.9091)$ & $(2.0370)$ & $(2.7918)$ \\
\hline \multicolumn{5}{|c|}{ Panel D: Higher Education } \\
\hline & All Donors & Individuals & Corporations & Foundations \\
\hline \multirow[t]{2}{*}{$\beta: \mathrm{S} \& \mathrm{P} 500$} & 0.0849 & $0.1117 * * *$ & 0.0048 & -0.0315 \\
\hline & $(0.0453)^{*}$ & $(0.0309)$ & $(0.0111)$ & $(0.0256)$ \\
\hline \multirow[t]{2}{*}{$\beta: \mathrm{GDP}$} & $0.1340 * *$ & $0.1276^{* *}$ & -0.0001 & 0.0065 \\
\hline & $(0.0612)$ & $(0.0399)$ & $(0.0100)$ & $(0.0308)$ \\
\hline \multirow[t]{2}{*}{$\beta: \mathrm{PCE}$} & 7.8605 & $12.4368 * *$ & -0.6167 & -3.9596 \\
\hline & $(6.3767)$ & $(4.7300)$ & $(1.5553)$ & $(3.1791)$ \\
\hline \multirow[t]{2}{*}{$\beta$ : Unemployment } & $-37.1820 * *$ & $-31.2054 * * *$ & -0.5243 & -5.4524 \\
\hline & $(16.4692)$ & $(10.4050)$ & $(2.4208)$ & $(8.9873)$ \\
\hline \multirow[t]{2}{*}{$\beta$ : Recession } & -4.0864 & -1.3086 & -3.5802 & 0.8025 \\
\hline & (22.6204) & $(16.0732)$ & $(6.0822)$ & $(5.4817)$ \\
\hline
\end{tabular}

Notes: Each panel shows a separate OLS regression with a different independent variable as an indicator economic health $(\beta)$, reporting the variable's coefficient from a regression: Number of Gifts ${ }_{d s, t}=\alpha+$ BIndicator $_{t}+\gamma$ Year $_{t}+\zeta$ Quarter $_{t}+\varepsilon_{d s, t}$.

Robust standard errors in parentheses.

$* * *$ Significant at the 1 percent level.

**Significant at the 5 percent level

*Significant at the 10 percent level 
Table 6: Impact of economic indicators on incidence of million dollar-plus giving in the same quarter

Poisson Regression

Dependent variable: Number of million-dollar-plus gifts per quarter by each donor type

Notes: Each cell shows a separate Ordinary Least Squares (OLS) regression with a different independent variable as an indicator economic health $(\beta)$, reporting the variable's coefficient from a regression: Number of Gifts d,$t=\alpha+\beta$ Indicator $_{t}+\gamma$ Year $_{t}+\zeta$ Quarter $_{t}+$ $\varepsilon_{d s, t} \cdot$

Panel A: $S \& P 500$

All Donors Individuals Corporations Foundations

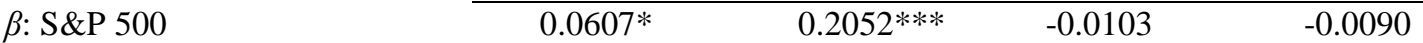

$\begin{array}{llll}(0.0337) & (0.0406) & (0.097) & (0.0437)\end{array}$

Panel B: GDP

All Donors Individuals Corporations Foundations

$\beta$ : GDP

$\begin{array}{lllc}0.2388^{* *} & 0.3298^{*} & 0.9146^{* * *} & 0.1491 \\ (0.0977) & (0.1796) & (0.337) & (0.1235)\end{array}$

Panel C: PCE

All Donors Individuals Corporations Foundations

$\beta$ : PCE

$\begin{array}{lccc}0.1789 * * & 0.2245 & 0.7759 * * * & 0.1083 \\ (0.0812) & (0.1527) & (0.280) & (0.1065)\end{array}$

Panel D: Unemployment rate

All Donors Individuals Corporations Foundations

$\beta$ : Unemployment Rate

$\begin{array}{llll}-0.0370^{* * *} & -0.0786^{* * *} & 0.0620 & -0.0478^{*} \\ (0.0140) & (0.0253) & (0.055) & (0.0248)\end{array}$

Panel E: Recession

All Donors Individuals Corporations Foundations

$\beta:$ Recession

$\begin{array}{llll}0.0469^{* * *} & 0.0258 & 0.0934^{* *} & 0.0685^{* * *}\end{array}$

$(0.0111)$

$(0.0248)$

$(0.039)$

$(0.0129)$

\begin{tabular}{lllr}
\hline$N$ & 19,077 & 7,092 & 3,003 \\
\hline
\end{tabular}

Notes: The dependent variable and all independent variables are in log form, except the dummy variable for recession.

Robust standard errors in parentheses.

$* * *$ Significant at the 1 percent level.

**Significant at the 5 percent level.

*Significant at the 10 percent level. 